\title{
Diversity in Anthropogenic Environment - Permanent Puddle as a Place for Development of Diatoms
}

\author{
Mateusz Rybak ${ }^{1 *}$, Teresa Noga ${ }^{2}$, Anita Poradowska ${ }^{3}$ \\ 1 Department of Agroecology, Faculty of Biology and Agriculture, University of Rzeszów, Ćwiklińskiej 1a, 35- \\ 601 Rzeszów, Poland \\ 2 Department of Soil Science, Environmental Chemistry and Hydrology, Faculty of Biology and Agriculture, \\ University of Rzeszów, A. Zelwerowicza 8B, 35-601 Rzeszów, Poland \\ 3 Department of Landscape Architecture, Faculty of Biology and Agriculture, University of Rzeszow, Ćwiklińskiej \\ 1A, 35-601 Rzeszow, Poland \\ * Corresponding author's e-mail: matrybak91@gmail.com
}

\begin{abstract}
Specific conditions in urban areas favour large species richness, these are also places prone to the anthropogenic pressure. As a result, many studies on aquatic habitats in urban ecosystems have been carried out. The aim of this study was to investigate the diversity of diatom assemblages developing in artificial environment in relation to water chemical parameters. The study was performed on a small water outflow in south-eastern Poland, which started in the storm sewage. The water at the studied sites was characterized by alkaline $\mathrm{pH}$ and low content of nutrients. The values of other chemical parameters were highly variable, depending on the research season. A total of 113 taxa were identified in five research seasons; most of them prefer circumneutral and fertile habitats, with a high content of biogens and are tolerant to water pollutions. Aerophytic and terrestrial taxa were observed in the analyzed materials in high diversity.
\end{abstract}

Keywords: Bacillariophyta, urban ecology, artificial environments, urban stream syndrome

\section{INTRODUCTION}

The urban landscape is becoming more and more widespread on a global scale. The man who shapes it, directly or indirectly influences the organisms inhabiting the changed area. The ecological processes that take place in cities are subject to similar rules as those occurring under natural conditions. Urban ecology is a fast-growing, interdisciplinary field of science, related to the research on the organisms living in the city and their relationships with the environment transformed by human. The aim of urban ecology is to identify the mechanisms of urban ecosystems functioning and the risks, in relation to continuous human pressure (Niemelä 1999, Sukopp 2002). In cities, the majority of space is occupied by building, streets and squares, modifying the thermal and humidity conditions of both the atmosphere and the soil. In many cities, natural surface watercourses have been reduced, completely eliminated them or hiding underground. This phenomenon led to the drying of soil and lowering of the groundwater level (Zimny 2006).

Due to the high susceptibility of water reservoirs to the impact of anthropogenic pressure, the research on water habitats is frequently conducted in urban ecosystems (Walsh et al. 2005). However, in Poland there are sparse studies on biodiversity in urban waters, mainly concerning benthic macroinvertebrates (Obolewski 2010). In recent years, a study on the diversity of diatom assemblages in few anthropogenically modified streams has been conducted on the territory of Rzeszów City (Noga et al. 2013b, 2016c). The current algological studies on the diversity of diatoms in artificial environments are limited and focused on the species growing on the walls of various buildings (Norbäck Ivarsson et al. 2013, Noga et al. 2016a). 
The aim of the study was to investigate the diversity of diatom assemblages developing in artificial environment in relation to the chemical parameters of water $(\mathrm{pH}$, conductivity and dissolved ions). In this paper, rare species of diatoms were distinguished and the ecological preferences of individual taxa were determined.

\section{METHODS}

The study was conducted on a small outflow of drainage water in south-eastern Poland (503' $\left.17.67^{\prime \prime} \mathrm{N}, 22^{\circ} 04^{\prime} 33.78^{\prime \prime} \mathrm{E}\right)$, which started in the storm sewage. During the material sampling in March and June 2016, the water flowed on the surface of the asphalt road ca. $250 \mathrm{~m}$ and drifted into a small puddle. From November 2016, the materials for studies were collected only from a puddle, because the water stopped flowing from the storm sewage. The puddle had variable size and water level (from a few millimeters to ca. $10 \mathrm{~cm}$ depth) which depended on the precipitation level, but it was present throughout the entire period of research.

The research material comprised the sediments accumulated on the surface of the road and parts of land plants submerged in water. In March and June 2016, the samples were collected both, from storm sewage and puddle, in November 2016, January and March 2017, the material was taken only from a puddle. For the first time (March 2016), the samples were collected only for diatom assemblage study; therefore, no chemical analysis was performed. Water electrolytic conductivity and $\mathrm{pH}$ were measured in situ. A detailed water chemical analysis was performed in a laboratory using a DIONEX ICS-5000 + DC
Thermo scientific ion chromatograph. Part of each diatom material was cleaned with a mixture of sulfuric acid and potassium dichromate. After complete dissolution of organic matter, the samples were washed in a centrifuge (at $2500 \mathrm{rpm}$ ) several times, until the chromic mixture had been removed. The cleaned material was mounted in syntetic resin - Pleurax (refractive index 1.75), identified and counted under a Carl Zeiss Axio Imager A2 light microscope (LM) under 1000× magnification, with differential interference contrast (DIC) with oil immersion and under scanning electron microscope (SEM) Hitachi SU8010.

Ecological characterization and identification of diatoms were performed according to Krammer (2000), Lange-Bertalot (2001), Hofmann et al. (2011), Levkov et al. (2013, 2017) and Lange-Bertalot et al. (2017). The species composition was determined by counting 300 valves on randomly selected fields of view under LM. The species with a relative frequency over $5 \%$ of all counted valves in the sample were defined as the dominant taxa. The ecological preferences of diatoms in relation to $\mathrm{pH}$, salinity, moisture, trophy and saproby were determined based on the Van Dam et al. (1994) classification. The categories of endangered for diatom taxa were distinguished using the Red List of the Algae in Poland (Siemińska et al. 2006).

\section{RESULTS}

The water on the studied site was alkaline (pH 7.8-9.4) and characterized by low values of biogens, except nitrates in June 2016 $\left(11.57 \mathrm{mg} \mathrm{l}^{-1}\right)$. The values of other chemical parameters were characterized by high

Table 1. Physico-chemical parameters of water at sampling site in Stalowa Wola city

\begin{tabular}{|c|c|c|c|c|}
\hline Sampling date & $\begin{array}{c}\text { June } \\
2016\end{array}$ & $\begin{array}{c}\text { November } \\
2016\end{array}$ & $\begin{array}{c}\text { January } \\
2017\end{array}$ & $\begin{array}{c}\text { March } \\
2017\end{array}$ \\
\hline $\mathrm{pH}$ & 9.4 & 7.9 & 7.9 & 3.8 \\
\hline Conductivity $\left[\mu \mathrm{S} \mathrm{cm}^{-1}\right]$ & 347 & 13250 & 22100 & 40.83 \\
\hline $\mathrm{Cl}^{-}\left[\mathrm{mg} \mathrm{l}^{-1}\right]$ & 64.56 & 4455.45 & 6195.00 & 14.82 \\
\hline $\mathrm{SO}_{4}{ }^{2-}\left[\mathrm{mg} \mathrm{l}^{-1}\right]$ & 74.02 & 21.35 & 36.44 & $<0.01$ \\
\hline $\mathrm{NO}_{3}^{-}\left[\mathrm{mg} \mathrm{l}^{-1}\right]$ & 11.57 & $<0.01$ & $<0.01$ & $<0.01$ \\
\hline $\mathrm{PO}_{4}{ }^{3-}\left[\mathrm{mg} \mathrm{l}^{-1}\right]$ & $<0.01$ & $<0.01$ & $<0.01$ & 0.05 \\
\hline $\mathrm{NH}_{4}{ }^{+}\left[\mathrm{mg} \mathrm{l}^{-1}\right]$ & 0.29 & $<0.01$ & $<0.01$ & 48.23 \\
\hline $\mathrm{Na}^{+}\left[\mathrm{mg} \mathrm{l}^{-1}\right]$ & 43.04 & 2689.24 & 3789.10 & 3.50 \\
\hline $\mathrm{K}^{+}\left[\mathrm{mg} \mathrm{l}^{-1}\right]$ & 24.43 & 66.72 & 46.65 & 6.26 \\
\hline $\mathrm{Mg}^{2+}\left[\mathrm{mg} \mathrm{l}^{-1}\right]$ & 8.35 & 38.48 & 21.98 & 9.45 \\
\hline $\mathrm{Ca}^{2+}\left[\mathrm{mg} \mathrm{l}^{-1}\right]$ & 41.73 & 145.86 & 125.50 & \\
\hline
\end{tabular}


variability in particular study seasons, especially electrolytic conductivity (347-22 $100 \mu \mathrm{S} \mathrm{cm}$ 1) and chlorine ion content (40.83-6 $195.00 \mathrm{mg}$ $\left.\mathrm{l}^{-1}\right)$, sodium (43.04-3 $\left.789.10 \mathrm{mg}^{-1}\right)$ and calcium (9.45-145.86 $\left.\mathrm{mg} \mathrm{l}^{-1}\right)$ (Table 1).

During the five research seasons, a total of 113 diatom taxa were identified, the number of which varied from 51 to 80 taxa in particular seasons. The most taxa were found in the following genera: Nitzschia (15), Luticola (13) and $\mathrm{Na}$ vicula (9). Ten taxa were considered as dominant (Table 2). The most numerous populations were created by Nitzschia palea (Kützing) W. Smith var. palea, which dominated on each research season $(8.1-74 \%)$.

In the study material, a new diatom species Stauroneis saprophila M. Rybak, Noga \& Ector (Noga et al. 2017) was described, and 6 species from the Red List of Polish Algae were found. Additionally, five new species (for Poland) have also been identified in this study in the genus Luticola (Table 2).
In each research season, many aerophytic and terrestrial taxa have been observed. These were mainly species of the following genera: Hantzschia, Humidophila, Luticola, Mayamaea, Muelleria, Pinnularia and Stauroneis.

The ecological preferences of individual diatom taxa developing at the studied sites were determined based on the Van Dam et al. (1994). In terms of the $\mathrm{pH}$, the circumneutral (25.0-72.7\%) and alkaliphilous (15.4-65.5\%) taxa were dominant. No species preferred low pH (i.e. acidobiontic and acidophilous) were found.

In terms of salinity, fresh brackish species $(65.5-90.5 \%)$ were the dominant group, the other groups usually did not exceed a few percent of the share in the assemblage. The brackish fresh species developed in greater number (13.6-23.6\%) only in January and March 2017.

Considering the parameter of the saproby, polysaprobic, $\alpha$-meso-/polysaprobic and $\alpha$-mesosaprobic diatoms developed most frequently, and their share has changed over the studied

Table 2. The list of diatom taxa determined on site in Stalowa Wola City in years 2016-2017 with threat categories KZ (according to Siemińska et al. 2006; R - rare taxa), * - taxa new to polish diatom flora; for dominat species $(>5 \%)$ percentage share in assemblage is given

\begin{tabular}{|c|c|c|c|c|c|c|}
\hline & 03.2016 & 06.2016 & 11.2016 & 01.2017 & 03.2017 & $\mathrm{KZ}$ \\
\hline Achnanthes coarctata (Brébisson) Grunow & + & + & + & + & + & $\mathrm{R}$ \\
\hline Amphora pediculus (Kützing) Grunow & & + & & & & \\
\hline Amphora sp. & & + & & & & \\
\hline Aulacoseira granulata (Ehrenberg) Simonsen & + & + & + & & + & \\
\hline Caloneis fontinalis (Grunow) Cleve-Euler & & & + & + & + & $\mathrm{R}$ \\
\hline Caloneis macedonica Hustedt & & & + & + & & \\
\hline Caloneis silicula (Ehrenberg) Cleve & & & + & & + & \\
\hline Caloneis cf. bacillum (Grunow) Cleve & & & + & & + & \\
\hline $\begin{array}{l}\text { Chamaepinnularia krookii } \\
\text { (Grunow) Lange-Bertalot \& Krammer }\end{array}$ & & & & & + & $\mathrm{R}$ \\
\hline Cocconeis lineata Ehrenberg & + & & & & & \\
\hline Craticula accomoda (Hustedt) D.G. Mann & & + & + & + & & \\
\hline Craticula ambigua (Ehrenberg) D.G. Mann & & + & + & + & + & \\
\hline Craticula buderi (Hustedt) Lange-Bertalot & & & & & + & \\
\hline Craticula cuspidata (Kutzing) D.G. Mann & & + & & & + & \\
\hline Craticula minusculoides (Hustedt) Lange-Bertalot & + & $10.3 \%$ & $5 \%$ & $8.1 \%$ & + & \\
\hline Craticula molestiformis (Hustedt) Mayama & + & + & & + & + & \\
\hline $\begin{array}{l}\text { Craticula subminuscula } \\
\text { (Manguin) C.E. Wetzel \& Ector }\end{array}$ & & + & + & + & + & \\
\hline Cyclostephanos dubius (Hustedt) Round & & & + & & & \\
\hline Cyclotella meneghiniana Kützing & & + & + & + & + & \\
\hline Cyclotella ocellata Pantocsek & & + & + & & & \\
\hline Cymatopleura solea (Brébisson) W. Smith & & & + & & & \\
\hline Diadesmis confervacea Kützing & & & + & + & & \\
\hline Diatoma vulgaris Bory & & & + & & & \\
\hline $\begin{array}{l}\text { Discostella pseudostelligera } \\
\text { (Hustedt) Houk \& Klee }\end{array}$ & & + & + & & + & \\
\hline Epithemia sp. & & & + & & & \\
\hline Fallacia monoculata (Hustedt) D.G. Mann & + & & & & & \\
\hline
\end{tabular}


Table 2 cont.

\begin{tabular}{|c|c|c|c|c|c|c|}
\hline & 03.2016 & 06.2016 & 11.2016 & 01.2017 & 03.2017 & $\mathrm{KZ}$ \\
\hline Fallacia insociabilis (Krasske) D.G. Mann & & & + & & + & \\
\hline Fistulifera pelliculosa (Kützing) Lange-Bertalot & & + & + & & + & \\
\hline $\begin{array}{l}\text { Fistulifera saprophila (Lange-Bertalot \& } \\
\text { Bonik) Lange-Bertalot }\end{array}$ & + & $23.4 \%$ & $6.1 \%$ & + & + & \\
\hline Frustulia vulgaris (Thwaites) De Toni & & & & & + & \\
\hline Gomphonema gracile Ehrenberg & & + & & & & \\
\hline Gomphonema italicum Kützing & & + & & & & \\
\hline $\begin{array}{l}\text { Gomphonema olivaceum } \\
\text { (Hornemann) Brébisson }\end{array}$ & + & & & & & \\
\hline $\begin{array}{l}\text { Gomphonema saprophilum } \\
\text { (Lange-Bertalot \& Reichardt) Abraca, et al. }\end{array}$ & + & $12.2 \%$ & $5.2 \%$ & + & + & \\
\hline Halamphora montana (Krasske) Levkov & + & + & + & + & + & \\
\hline Halamphora veneta (Kützing) Levkov & + & + & + & + & + & \\
\hline Hantzschia abundans Lange-Bertalot & + & + & + & + & + & \\
\hline Hantzschia amphioxys (Ehrenberg) Grunow & + & + & + & + & + & \\
\hline Hantzschia calcifuga Reichardt \& Lange-Bertalot & & + & + & & + & \\
\hline Hantzschia subrupestris Lange-Bertalot & + & + & + & + & + & \\
\hline Humidophila contenta (Grunow) Lowe et al. & + & + & + & + & + & \\
\hline Luticola acidoclinata Lange-Bertalot & + & + & + & + & & $\mathrm{R}$ \\
\hline *Luticola obscura Levkov, et al. & + & + & + & + & + & \\
\hline *Luticola pseudonivalis (W. Bock) Levkov, et al. & & + & & & + & \\
\hline *Luticola pulchra (McCall) Levkov, et al. & + & + & + & & + & \\
\hline *Luticola saprophila Levkov, et al. & & & + & & & \\
\hline Luticola sparsipunctata Levkov, et al. & + & + & + & + & + & \\
\hline *Luticola vanheurckii Van de Vijver \& Levkov & & + & + & + & + & \\
\hline Luticola ventricosa (Kützing) D.G. Mann MT1 & + & + & + & + & + & \\
\hline Luticola ventricosa (Kützing) D.G. Mann MT2 & + & + & + & + & + & \\
\hline Luticola sp. 1 & + & & + & + & & \\
\hline Luticola sp. 2 & + & & & & + & \\
\hline Luticola cf. nivalis (Ehrenberg) D.G. Mann & + & + & & & & \\
\hline Luticola sp. 4 & + & + & + & + & + & \\
\hline Mayamaea asellus (Weinhold) Lange-Bertalot & + & + & + & & + & \\
\hline Mayamaea atomus (Kützing) Lange-Bertalot & + & + & + & + & + & \\
\hline Mayamaea excelsa (Krasske) Lange-Bertalot & + & + & & + & + & $\mathrm{R}$ \\
\hline Mayamaea fossalis (Krasske) Lange-Bertalot & + & + & + & & & \\
\hline Mayamaea permitis (Hustedt) Bruder \& Medlin & + & + & + & & & \\
\hline Muelleria gibbula (Cleve) Spaulding \& Stoermer & + & & + & & + & \\
\hline Navicula antonii Lange-Bertalot & & & & + & + & \\
\hline Navicula cincta (Ehrenberg) Ralfs & + & & & & & \\
\hline Navicula cryptocephala Kützing & & + & & & + & \\
\hline Navicula erifuga Lange-Bertalot & & & + & + & + & \\
\hline Navicula trivialis Lange-Bertalot & & + & + & $8.9 \%$ & $5.5 \%$ & \\
\hline Navicula veneta Kützing & + & + & + & $5.9 \%$ & + & \\
\hline $\begin{array}{l}\text { Navicula vilaplanii (Lange-Bertalot \& Sabater) } \\
\text { Lange-Bertalot \& Sabater }\end{array}$ & & & + & + & + & \\
\hline Navicula wiesneri Lange-Bertalot & + & + & + & $5.2 \%$ & $8.2 \%$ & \\
\hline Navicula cf. notha J.H. Wallace & & & + & & & \\
\hline Neidium longiceps (Gregory) Ross & & + & & & + & \\
\hline Nitzschia acicularis (Kützing) W. Smith & & + & & & & \\
\hline Nitzschia amphibia Grunow & + & & + & + & + & \\
\hline Nitzschia capitellata Hustedt & + & + & + & + & + & \\
\hline Nitzschia communis Rabenhorst & $5.1 \%$ & + & + & + & + & \\
\hline Nitzschia dissipata (Kützing) Rabenhorst & & & & & + & \\
\hline Nitzschia draveillensis Coste \& Ricard & & + & & & & \\
\hline Nitzschia frustulum (Kützing) Grunow & & + & + & $5.2 \%$ & $5 \%$ & \\
\hline Nitzschia linearis W. Smith & & + & + & & + & \\
\hline
\end{tabular}


Table 2 cont.

\begin{tabular}{|c|c|c|c|c|c|c|}
\hline & 03.2016 & 06.2016 & 11.2016 & 01.2017 & 03.2017 & $\mathrm{KZ}$ \\
\hline Nitzschia palea var. minuta (Bleisch) Grunow & & + & + & + & & \\
\hline Nitzschia palea var. debilis (Kützing) Grunow & + & + & + & & & \\
\hline Nitzschia palea (Kützing) W. Smith var. palea & $55.3 \%$ & $45.3 \%$ & $74 \%$ & $8.1 \%$ & $13.2 \%$ & \\
\hline Nitzschia pusilla Grunow & + & + & + & & & \\
\hline Nitzschia solgensis Cleve-Euler & & & + & & + & \\
\hline Nitzschia tubicola Grunow & & + & & & & \\
\hline Nitzschia umbonata (Ehrenberg) Lange-Bertalot & & + & + & + & + & \\
\hline Pinnularia borealis Ehrenberg & + & + & + & + & + & \\
\hline Pinnularia brebissonii (Kützing) Rabenhorst & + & + & + & + & + & \\
\hline Pinnularia cuneola Reichardt & & + & & + & + & \\
\hline Pinnularia issealana Krammer & & + & & & + & \\
\hline Pinnularia obscura Krasske & + & + & & + & + & \\
\hline $\begin{array}{l}\text { Planothidium frequentissimum } \\
\text { (Lange-Bertalot) Lange-Bertalot }\end{array}$ & & + & + & + & + & \\
\hline $\begin{array}{l}\text { Planothidium lanceolatum } \\
\text { (Brébisson) Lange-Bertalot }\end{array}$ & & & & & + & \\
\hline $\begin{array}{l}\text { Rhoicosphenia abbreviata } \\
\text { (C. Agardh) Lange-Bertalot }\end{array}$ & & + & & + & & \\
\hline Rhopalodia gibba (Ehrenberg) Müller & & & + & + & & \\
\hline $\begin{array}{l}\text { Sellaphora atomoides (Grunow) C.E. Wetzel \& } \\
\text { Van de Vijver }\end{array}$ & + & + & + & + & + & \\
\hline Sellaphora nigri (De Notaris) C.E. Wetzel \& Ector & + & + & + & + & + & \\
\hline Sellaphora pupula (Kützing) Mereschkovsky & & + & + & + & + & \\
\hline $\begin{array}{l}\text { Sellaphora saugerresii } \\
\text { (Desmazières) C.E. Wetzel \& D.G. Mann }\end{array}$ & + & + & + & + & + & \\
\hline Stauroneis borrichii (Petersen) Lund & + & + & & + & + & \\
\hline Stauroneis Iundii Hustedt & & & + & & + & \\
\hline Stauroneis reinhardtii Grunow & + & & & & + & \\
\hline Stauroneis saprophila M.Rybak, Noga \& Ector & + & + & + & + & + & \\
\hline Stauroneis thermicola (Petersen) Lund & & & + & & & $\mathrm{R}$ \\
\hline Stephanodiscus invisitatus Hohn \& Hellermann & & + & & & & \\
\hline Surirella angusta Kützing & + & + & + & + & + & \\
\hline $\begin{array}{l}\text { Surirella brebissonii var. kuetzingii } \\
\text { Krammer \& Lange-Bertalot }\end{array}$ & + & + & & + & + & \\
\hline Surirella minuta Brébisson & + & + & + & $5.2 \%$ & $8.2 \%$ & \\
\hline Surirella ovalis Brébisson & & & + & & & \\
\hline Surirella terricola Lange-Bertalot \& E. Alles & & & + & & + & \\
\hline Tryblionella debilis Arnott & & & & + & & \\
\hline Tryblionella apiculata Gregory & & + & + & + & + & \\
\hline Tryblionella hungarica (Grunow) Frenguelli & & + & + & + & + & \\
\hline Total numer of taxa: 113 & 51 & 76 & 80 & 60 & 76 & 6 \\
\hline
\end{tabular}

seasons. In 2016, $\alpha$-meso/polysaprobic species (14.7-38.3\%) and polysaprobic (33.8-48.1\%) developed most frequently, while in 2017 $\alpha$-mesosaprobic (21.4-25.7\%) and $\alpha$-meso-/ polysaprobic species prevailed (25.0-36.5\%).

In all the research seasons, the diatoms preferring high trophic waters have been observed abundantly. In 2016, hypereutrophic species (36.8-50.4\%) and eutrophic (38.2-38.8\%) dominated, while in 2017 - the eutrophic taxa (56.4-62.8\%).

In terms of environment humidity, the most numerous group were the taxa mainly occurring in water habitats (48.6-71.0\%) and the taxa mainly occurring on wet and moist or temporarily dry places $(25.7-32.4 \%)$.

\section{DISCUSSION}

The small outflow of water from the sewer well in the city of Stalowa Wola was characterized by a very high content of electrolytes (347-22 $100 \mu \mathrm{S} \mathrm{cm}^{-1}$ ), especially in the period from November 2016. Very high concentration of chlorides and sodium ions was 


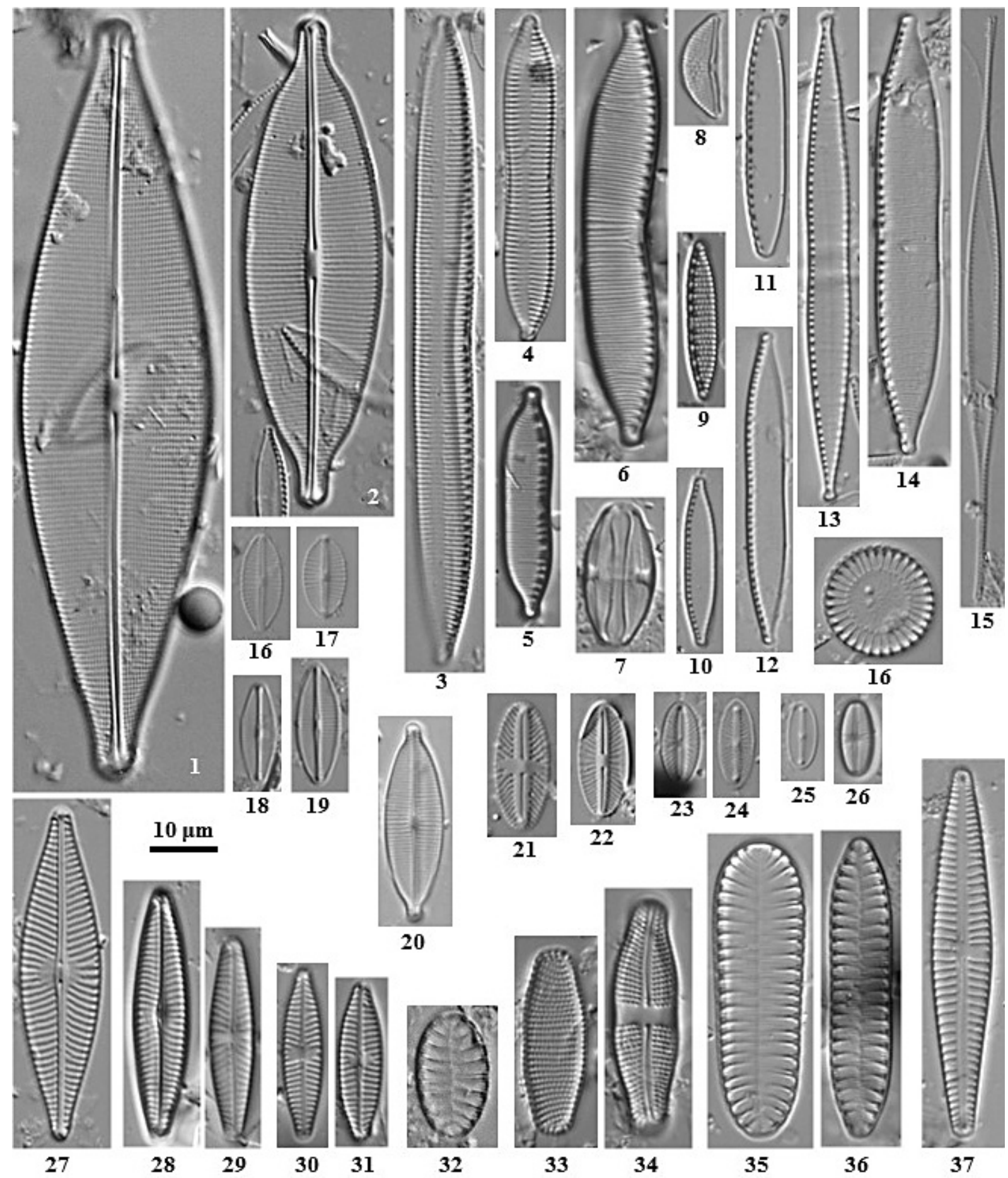

Figure 1. Selected diatom species recorded in analyzed materials (LM - microphotographs): 1 - Craticula cuspidata, 2 - C. ambigua, 3 - Tryblionella hungarica, 4 - T. apiculata, 5 - Hantzschia amphioxys, 6 - H. abundans, 7 - Halamphora montana, 8-H. veneta, 9-N. amphibia, $10-N$. palea, $11-N$. communis, 12,13-N. capitellata, 14 - N. umbonata, 15 - N. acicularis, 16 - Cyclotella meneghiniana, 16,17 - Craticula subminuscula, 18 Craticula molestiformis, 19 - C. minusculoides, 20-C. accomoda, 21 - Mayamaea asellus, 22 - M. excels, 23,24 - M. atomus, 25 - M. permitis, 26 - Sellaphora nigri, 27 - Navicula trivialis, 28 - N. erifuga, 29 - N. wiesneri, 30,31 - N. veneta, 32 - Surirella brebissonii var. kuetzingii, 33,34 - Achnanthes coarctata, 35 - Surirella minuta, 36 - S. angusta, 37 - Gomphonema gracile

observed in the winter season, which could be caused by sprinkling roads with salt $(\mathrm{NaCl})$. This unusual habitat was characterized by a large species richness of diatoms, among which the largest populations were created by Nitzschia palea var. palea. This species occurs in various 


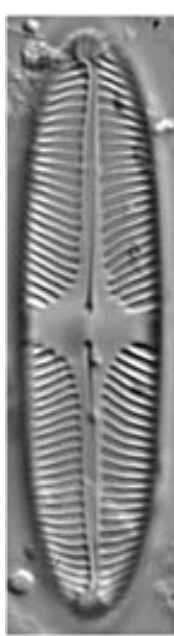

1

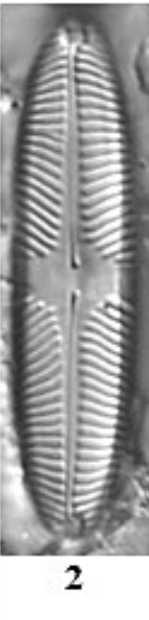

2
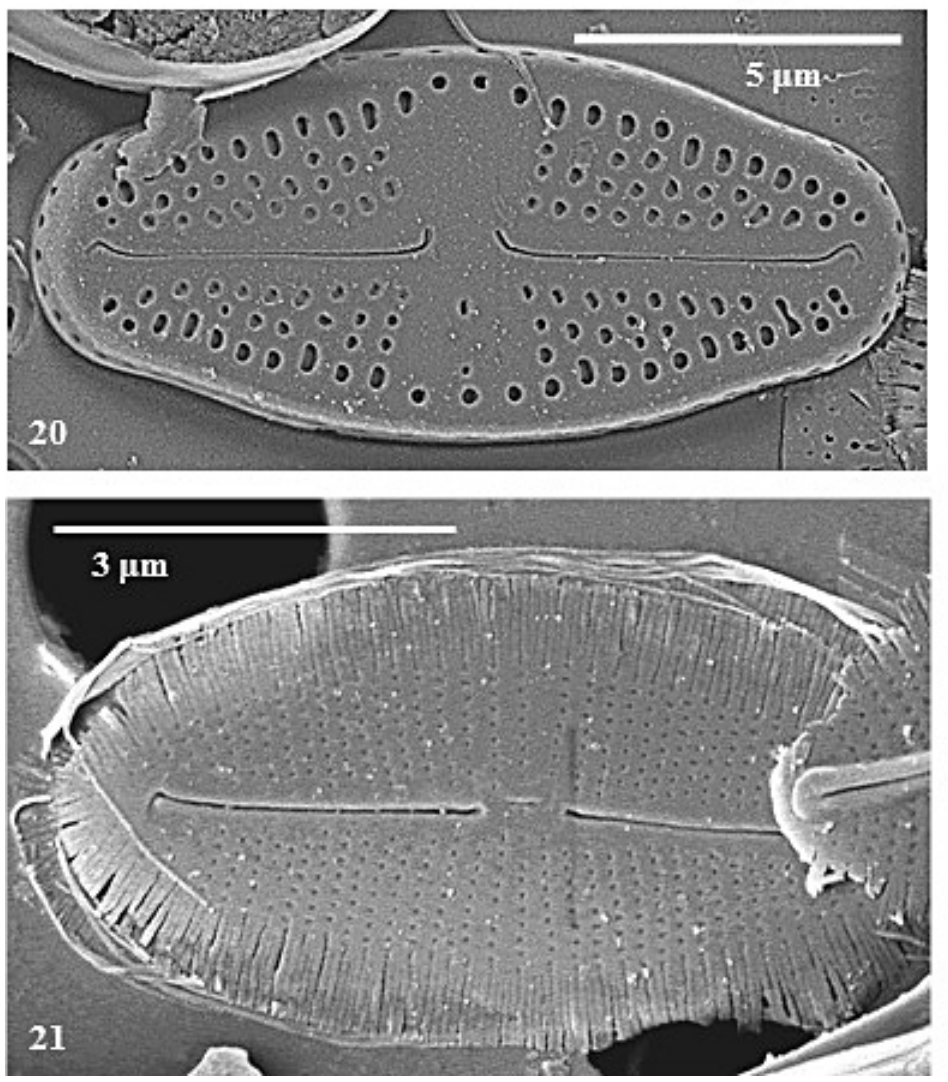

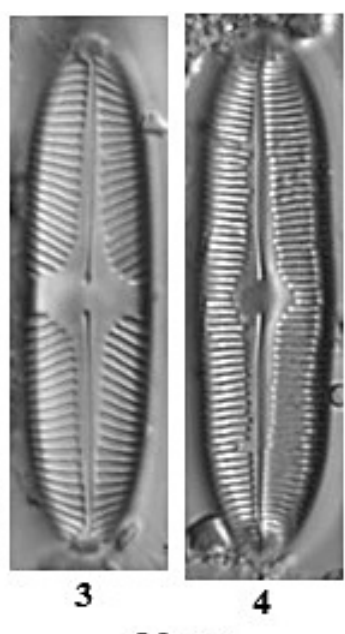

$10 \mu \mathrm{m}$

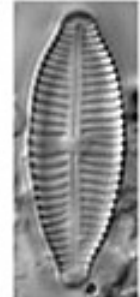

5

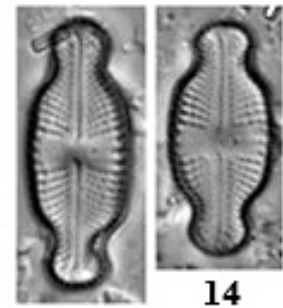

14

6

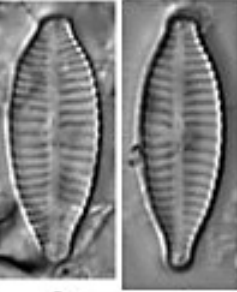

7

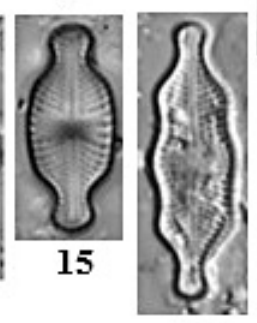

16
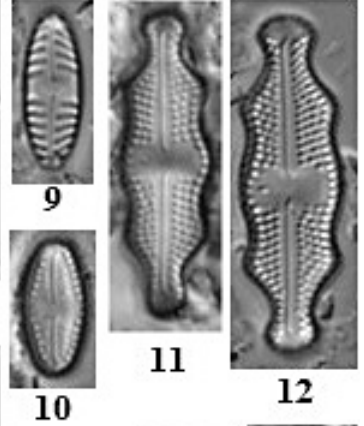

11

12
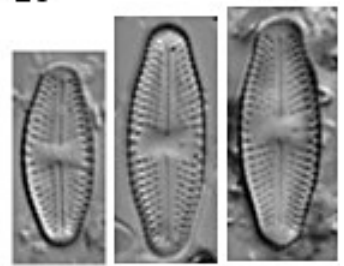

$\begin{array}{lll}17 & 18 & 19\end{array}$

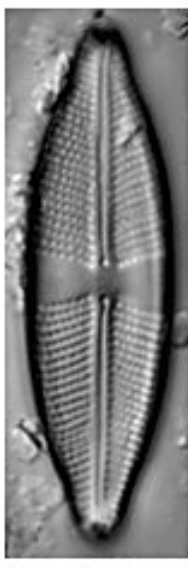

22

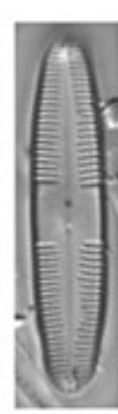

27

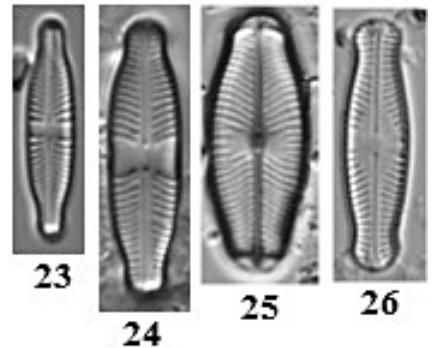

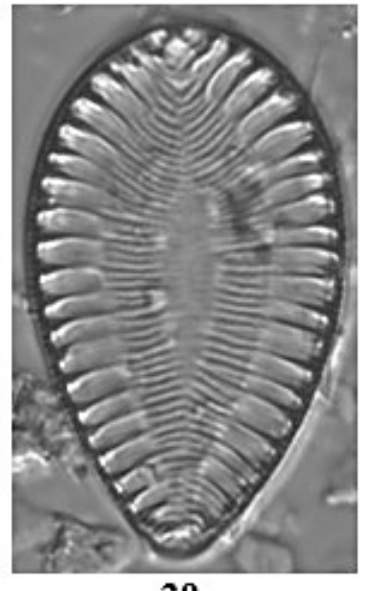

29

Figure 2. Selected diatom species in analyzed materials (1-19, 22-29 - LM microphotographs, 20, 21 - SEM - microphotographs): 1-3 - Pinnularia brebissonii, 4 - Caloneis silicula, 5-8 - Gomphonema saprophilum, 9 - Pinnularia obscura, 10 - Luticola sparsipunctata, 11-12 - L. cf. nivalis, 13-15 - L. ventricosa MT2, 16 - L. pseudonivalis, 17-20 - L. obscura, 21 - Fistulifera saprophila, 22 - Stauroneis saprophila, 23 - S. thermicola, 24 - S. borrichii, 25 - Sellaphora pupula, 26 - Chamaepinnularia krookii, 27 - Caloneis fontinalis, 28 - Pinnularia cuneola, 29 - Surirella ovalis

types of water, also on wet soil (Hofmann et al. 2011). Together with the afore-mentioned species, Fistulifera saprophila (Lange-Bertalot \& Bonik) Lange-Bertalot and Craticula minusculoides (Hustedt) Lange-Bertalot were also found frequently; however, they formed less numerous populations (5-23.4\%). All of these species develop in electrolyte-rich waters and prefer eutrophic, often saline waters. In addition, Fistulifera saprophila is considered to be the most tolerant diatom species with an optimum occurrence in heavily degraded and organically contaminated waters (Lange-Bertalot 2001, Hofmann et al. 2011). Except of Craticula minusculoides, other 
species of the Craticula genus also occurred in the diatom assemblage; however, all of them developed as individual specimens. The species belonging to the Craticula genus are often epipelic and occur in both, fresh and brackish waters. They prefer mainly eutrophic habitats and are resistant to organic pollutants (Lange-Bertalot 2001). For this reason, high electrolytic conductivity as well as content of $\mathrm{Cl}$ and $\mathrm{Na}$ ions in the studied material probably favored the development of the above-mentioned taxa.

Other organisms have also been observed in the studied material, including oligochaetes, chironomids and snail Physa acuta Draparnaud, 1805 , which often developed in the benthos of urban streams and have similar ecological preferences and are resistant to pollution like the dominant diatom species (Walsh et al. 2005).

In the material collected from sediments (a mixture of sand and silt), the new diatom species - Stauroneis saprophila M. Rybak, Noga \& Ector - has been identified and described (Noga et al. 2017). This species has also been recently found in other types of habitats, including the mosses growing on the bark trees (Rybak - unpublished data). For this reason, the authors believe that the species can develop in various habitats, both terrestrial and aerophytic. The conducted research also showed the occurrence of five species new to Poland, belonging to the Luticola genus. These are mainly aerophytic species (L. obscura, L. pseudonivalis, L. pulchra, L. vanheurckii) found in periodically wet areas such as mosses or soils or in freshwater habitats, often characterized with high saproby (L. saprophila) (Levkov et al. 2013, 2017). All species from the Luticola genus, in the studied material were developed in the form of single valves - only $L$. obscura was more numerous, reaching a $2 \%$ share in the assemblage. The ecology of this species is still poorly known, it was described for the first time in Macedonia, from the mosses growing on halomorphic soils - where it co-occurred with L. pulchra (Levkov et al. 2017). The present study confirms that this species prefers high electrolyte contents and aerophytic conditions.

Among many cosmopolitan taxa and the taxa commonly found in various habitat types, rare species (R category) from the Red List of Algae in Poland (Siemińska et al. 2006) were recorded. These were mainly terrestial taxa or those preferring a typical soil habitat, e.g.: Achnanthes coarctata, Mayamaea excelsa and Stauroneis thermicola (Lange-Bertalot 2001, Stanek-Tarkowska et al. 2013, Lange-Bertalot et al. 2017) or the taxa developing in large numbers among mosses, i.e. Luticola acidoclinata (Levkov et al. 2013, Rybak et al. 2018). Other rare species (Caloneis fontinalis and Chamaepinnularia krookii) develop in large numbers in eutrophic, often brackish waters near the sea coast (Krammer, Lange-Bertalot 1986, Hofmann et al. 2011).

A rare species of diatom (however, not included on the Red List of Algae in Poland) was Caloneis macedonica Hustedt, found in the studied material occurred individually. The species is found among others in the Balkans, Sinai and lakes in Northern Germany (Krammer, LangeBertalot 1986) as well as North America (Bahls 2006). In Poland, it is known only from several locations. It was found in the springs of central Poland (Żelazna-Wieczorek 2011) and in two sites in the Podkarpacie region, i.e. in the Mleczka River (Pajączek et al. 2012) and in the Przyrwa stream (Noga et al. 2016c). The ecology of this species is still poorly known. In south-eastern Poland - like in the studied material - the species develops in the form of individual specimens, on silty or sandy-silty substrata.

During each sampling, the study site was characterized by a large proportion of circumneutral ( $\mathrm{pH}$ close to 7) and alkaliphilous $(\mathrm{pH}>7)$ diatoms. Eutrophic and hypertrophic diatoms were very numerous, indicating high fertility of the habitat, whereas the saprobic parameter showed the dominance of taxa from meso- to polysaprobes, corresponding to III-V water quality class (Van Dam et al. 1994). Despite the fact that high nitrate content was found only in the summer of 2016 and the biogen values in the other sampling dates were below the level of determination, the diatom domination structure indicates high fertility of the habitat and high saproby. Domination of Nitzschia palea var. palea (Kützing) W. Smith also confirms this, because it is a species that prefers the conditions from $\alpha$-meso- to polysaprobes. It can also develop in untreated sewage and habitats contaminated by industrial wastewater (Lange-Bertalot et al. 2017). Similar ecological preferences are shown by the diatoms developing in large rivers in the Podkarpacie region, especially in the middle and lower courses, e.g. in the Wisłok and Wisłoka rivers (Noga et al. 2013a, 2016b). However, even in these rivers, eutrophic or wide-spectrum diatoms predominate - oligoeutrophic, while hypertrophic ones are usually less numerous. 
In all studied seasons, fresh brackish diatoms predominated (developing mainly in freshwater); however, in 2017 the share of brackish fresh diatoms increased (13.6-23.6\%); they prefer high concentrations of $\mathrm{Cl}^{-}\left(500-1000 \mathrm{mg} \mathrm{l}^{-1}\right)$, corresponding to salinity of $0.9-1.8 \%$ (Van Dam et al., 1994). This is confirmed by the predominant taxa of diatoms, among others Craticula minusculoides (Hustedt) Lange-Bertalot, Navicula veneta Kützing, $N$. wiesneri Lange-Bertalot, Nitzschia communis Rabenhorst and Nitzschia frustulum (Kützing) Grunow, as well as taxa developing individually, including Diadesmis confervacea Kützing, Halamphora veneta (Kützing) Levkov, Luticola obscura Levkov, Tofilovska, C.E.Wetzel, Mitic-Kopanja \& Ector, Navicula erifuga Lange-Bertalot, Surirella brebissonii var. kuetzingii Krammer \& Lange-Bertalot, Surirella ovalis Brébisson, or representatives of the Tryblionella genus that develop in waters with high electrolytes and often saline inland waters (LangeBertalot 2001, Lange-Bertalot et al. 2017).

High fluctuations in the surface of the research habitat favored the development of many aerophytic or even terrestrial taxa of the following genera: Hantzschia, Luticola, Mayamaea or Stauroneis. The diatoms representing these types are resistant to water scarcity and this is the reason why these taxa developed in high diversity in the studied materials (Van Dam et al. 1994, Hofmann et al. 2011, Levkov et al. 2013).

The presented research showed that atypical water habitats, arising in strongly transformed urban ecosystems, are the place of development of diatom assemblages, mainly cosmopolitan and very resistant, as well as poorly known, or even new to science, and therefore should not be overlooked in diatomological research.

\section{Acknowledgments}

The project, funded under the Ministry of Science and Higher Education under the name of "Regional Excellence Initiative" in the years 2019-2022 Project No. 026/RID/2018/19.

\section{REFERENCES}

1. Bahls L.L. 2006. Northwestern Diatoms. A photographic catalogue of species in the Montana Diatom Collection with ecological optima, associates, and distribution records for the nine northwestern United States. Vol. 3, Helena, Montana, Montana
Diatom Collection, $481 \mathrm{pp}$.

2. Hofmann G., Werum M., Lange-Bertalot H. 2011. Diatomeen im Süßwasser - Benthos von Mitteleuropa. Bestimmungsflora Kieselalgen für die ökologische Praxis. Über 700 der häugfisten Arten und ihre Ökologie. [In:] H. Lange-Bertalot, (Ed.): 908 pp. A.R.G. Gantner Verlag K.G., Ruggell.

3. Krammer K. 2000. The genus Pinnularia. [In:] H. Lange-Bertalot (Ed.): Diatoms of Europe. Vol. 1., 703 pp. A.R.G. Gantner Verlag K.G.

4. Krammer K., Lange-Bertalot H. 1986. Bacillariophyceae. 1. Naviculaceae. [In:] H. Ettl, J. Gerloff, H. Heyning, D. Mollenhauer (Eds): Süsswasserflora von Mitteleuropa 2(1), G. Fischer Verlag, 14 Stuttgart - New York, 876 pp.

5. Lange-Bertalot H. 2001. Navicula sensu stricto, 10 Genera Separated from Navicula sensu lato, Frustulia. [In:] H. Lange-Bertalot (Ed.): Diatoms of Europe 2. Diatoms of the European inland waters and comparable habitats. A.R.G. Gartner Verlag. K.G., Vaduz, $526 \mathrm{pp}$.

6. Lange-Bertalot H., Hofmann G., Werum M., Cantonati M. 2017. Freshwater benthic diatoms of Central Europe: over 800 common species used in ecological assessments. English edition with updated taxonomy and added species. [In:] M. Cantonati et al. (Eds): Koeltz Botanical Books, SchmittenOberreifenberg, $942 \mathrm{pp}$.

7. Levkov Z., Metzeltin D., Pavlov A. 2013. Luticola and Luticolopsis. [In:] H. Lange-Bertalot (Ed.): Diatoms of Europe 7. Diatoms of the European inland waters and comparable habitats. Koeltz Scientific Books, Königstein, 698 pp.

8. Levkov Z., Tofilovska S., Wetzel C.E., MitićKopanja D., Ector L. 2017. Diversity of Luticola D.G. Mann (Bacillariophyceae) species on halomorphic soils from Gladno Pole, Central Macedonia. Nova Hedwigia, Beiheft, 146, 175-196.

9. Niemelä J. 1999. Is there a need for a theory of urban ecology? Urban Ecosystem, 3, 57-65.

10. Noga T., Stanek-Tarkowska, Pajączek A., Peszek Ł., Kochman N. 2013a. Ecological characterization of diatom communities in the Wisłok river with application of their indicatory role to the evaluation of water quality. Journal of Ecological Engineering, 14(4), 18-27.

11. Noga T., Stanek-Tarkowska J., Peszek Ł., Pajączek A., Kowalska S. 2013b. Use of diatoms to assess water quality of anthropogenically modified Matysówka stream. Journal of Ecological Engineering, 14(2), 1-11.

12. Noga T., Stanek-Tarkowska J., Kochman-Kędziora N., Pajączek A., Peszek Ł. 2016a. The inside of a dam as an unusual habitat for two rare species of Gomphosphenia-G. fontinalis and G. holmquistii. Diatom Research, 31(4), 379-387. 
13. Noga T., Stanek-Tarkowska J., Peszek Ł., Pajączek A., Kochman-Kędziora N., Ligęzka R. 2016b. The use of diatoms to assess the water quality of the Wisłoka River in the Dębica City and surrounding area. Oceanological and Hydrobiological Studies, 45(2), 191-201.

14. Noga T., Stanek-Tarkowska J., Kloc U., KochmanKędziora N., Rybak M., Peszek Ł., Pajączek A. 2016c. Diatom diversity and water quality of a suburban stream: a case study of the Rzeszów city in SE Poland. Biodiversity Research and Conservation, 41, 19-34.

15. Noga T., Rybak M., Ector L. 2017. Description of Stauroneis saprophila sp. nov. (Bacillariophyta), a new diatom species from anthropogenic environment. Phytotaxa, 327(3), 269-275.

16. Norbäck Ivarsson L., Ivarsson M., Lundberg J., Sallstedt T., Rydin C. 2013. Epilithic and aerophilic diatoms in the artificial environment of Kungsträdgården metro station, Stockholm, Sweden. International Journal of Speleology, 42(3), 289-297.

17. Obolewski K. 2010. Use of macroinvertebrates as bioindicators for the assessment of surface water quality in urban areas: a case study. Ochrona Środowiska, 32(2), 35-42. (in Polish).

18. Pajączek A., Musiałek M., Pelczar J., Noga T. 2012. Diversity of diatoms in the Mleczka River, Morwawa River and Różanka Stream (tributaries of the Wisłok River, SE Poland), with particular reference to threatened species. [In:] K. Wołowski et al. (Eds): Phycological Reports: Current advances in algal taxonomy and its applications: phylogenetic, ecological and applied perspective. Institute of Botany Polish Academy of Sciences, Krakow, pp. 129-152.

19. Rybak M., Noga T., Zubel R. 2018. The aerophytic diatom assemblages developed on mosses covering the bark of Populus alba L. J. Ecol. Eng., 19(6), 113-123.

20. Siemińska J., Bąk M., Dziedzic J., Gąbka M., Gregorowicz P., Mrozińska T., Pełechaty M., Owsiany P.M., Pliński M., Witkowski A. 2006. Red list of the algae in Poland - Czerwona lista glonów w Polsce. [In:] Z. Mirek et al. (Eds): Red list of plants and fungi in Poland - Czerwona lista roślin i grzybów Polski. Polish Academy of Sciences, Kraków, pp. 35-52. (in Polish).

21. Stanek-Tarkowska J, Noga T, Pajączek A, Peszek Ł. 2013. The occurrence of Sellaphora nana (Hust.) Lange-Bert. Cavacini, Tagliaventi \& Alfinito, Stauroneis borrichii (J.B. Petersen) J.W.G. Lund, S. parathermicola Lange-Bert. and S. thermicola (J.B. Petersen) J.W.G. Lund on agricultural soils. Algological Studies, 142, 109-120.

22. Sukopp H. 2002. On the early history of urban ecology in Europe. Preslia, 74, 373-393.

23. Van Dam H., Martens A., Sinkeldam J. 1994. A coded checklist and ecological indicator values of freshwater diatoms from the Netherlands. Netherlands Journal of Aquatic Ecology, 28(1), 117-133.

24. Walsh C.J., Roy A.H., Feminella J.W., Cot- tingham P.D., Groffman P.M., Morgan II R.P., 2005. The urban stream syndrome: current knowledge and the search for a cure. J. North Am. Benthol. Soc., 24, 706-723.

25. Zimny H. 2006. Ecological evaluation of the state of the environment. Bioindication and biomonitoring. [Ekologiczna ocena stanu środowiska. Bioindykacja i biomonitoring], ARW A. Gregorczyk, Warszawa, 264 pp. (in Polish).

26. Żelazna-Wieczorek J. 2011. Diatom flora in springs of Łódź Hills (Central Poland). Biodiversity, taxonomy and temporal changes of epipsammic diatom assemblages in springs affected by human impact. Diatom Monographs, 13, 1-420. 